\title{
ОКИСНЮВАЛЬНА МОДИФІКАЦІЯ ПРОТЕЇНІВ У ЩУРІВ РІЗНОГО ВІКУ ЗА УМОВ ХРОНІЧНОГО УРАЖЕННЯ ВАЖКИМИ МЕТАЛАМИ І ГЛІФОСАТОМ
}

Вступ. Відомо, що вплив різних забруднювачів навколишнього середовища, таких, як важкі метали і оросфорорганічні сполуки, викликає різні зміни в організмі людини, які супроводжуються порушенням балансу між процесами окиснення і відновлення, утворенням активних фоорм Оксигену, що пояснює розвиток оксидантного стресу. Іони важких металів можуть індукувати утворення активних фрорм Оксигену. На сьогодні корекція порушень вільнорадикальних та антиокситантних процесів за комбінованої дії важких металів і фросфророрганічних пестицидів залишається не до кінця вивченою.

мета дослідження - вивчити вплив Плюмбуму ацетату, Купруму сульфрату і гліфосату в фрормі раундапу та коригувальну дію цистеїл-гістидил-тирозил-гістидил-ізолейцину на окиснювальні процеси в щурів різного віку.

Методи дослідження. Досліди проводили на лабораторних нелінійних білих щурах-самцях 3 вікових груп: статевонезрілих, статевозрілих і старих, яким внутрішньошлунково протягом 30 днів вводили водні розчини Плюмбуму ацетату, Купруму сульфрату і гліфосату (у фрормі гербіциду раундапу). 3 метою корекції на 21-й день через 6 год після введення токсикантів протягом 10 днів вводили пептид цистеїл-гістидил-тирозил-гістидил-ізолейцин. Оксидантний стрес оцінювали за рівнем окисномодиорікованих протеїнів, вмістом ТБК-активних продуктів і дієнових кон'югатів у сироватці крові та гомогенатах печінки.

Результати й обговорення. Встановлено, що при введенні щурам водних розчинів Плюмбуму ацетату, Купруму сульфату і гліфосату (у фрормі гербіциду раундапу) в комбінації активувалися окиснювальні процеси у сироватці крові та гомогенаті печінки уражених щурів. Одночасне введення досліджуваних ксенобіотиків тваринам усіх вікових груп викликало збільшення вмісту ТБК-активних продуктів і дієнових кон'югатів у сироватці крові та гомогенаті печінки. Інтоксикація Купруму сульфратом, Плюмбуму ацетатом і фросфророрганічним пестицидом супроводжувалася порушенням балансу між про- й антиоксидантами, розвитком оксидантного стресу, що може викликати фрункціональні та структурні ушкодження клітинних мембран і накопичення токсичних метаболітів. При використанні пептиду як чинника корекціі зменшувався вміст активних фрорм Оксигену та продуктів пероксидного окиснення ліпідів.

Висновок. Введення пептиду як коригувального чинника щурам із токсичним ураженням печінки знижує генерацію активних фрорм Оксигену та вміст продуктів вільнорадикального окиснення ліпідів.

КЛЮЧОВІ СЛОВА: вільні радикали; вільнорадикальне окиснення; Плюмбуму ацетат; Купруму сульфат; гліфосат.

ВСТУП. Основним джерелом енергії в клітинах $є$ процес окиснення певних субстратів. Цей процес може бути здійснений трьома основними шляхами: приєднанням кисню до атома вуглецю, відщепленням Гідрогену або втратою електрона. У клітинах тварин і людини окиснення перебігає у формі послідовного перенесення водню та електронів від субстрату до кінцевого акцептора електронів - молекулярного кисню. Отже, у живому організмі реакція відновлення $\mathrm{O}_{2} д_{0} \mathrm{H}_{2} \mathrm{O} \epsilon$ основою біоенергетики $[1,2]$. Вважають, що в нормі за фрізіологічних умов таким чином відновлюється близько $95 \%$ усього спожитого кисню в клітині, а решта $5 \%$ - перетворюється в так звані активні форми Оксигену (АФО) (ROS, () Є. Б. Дмухальська, Т. Я. Ярошенко, 2021.
Reactive Oxygen Species). Утворення АФО під час фагоцитозу є одним із ключових механізмів захисту від патогенних мікроорганізмів [3]. Аеробні організми стикаються з постійною небезпекою, пов'язаною з тим, що багато процесів зучастю молекулярного кисню супроводжується утворенням АФО, які володіють надзвичайно високою реакційною здатністю - миттєво реагують з молекулами, що безпосередньо зв'язані 3 ними. До таких молекул належать протеїни, мембранні ліпіди, вуглеводи, нуклеїнові кислоти. У цьому випадку АФО є основним чинником клітинного ушкодження [4, 5].

Однак, коли АФО утворюється забагато, вони можуть вступати в реакцію з різними молекулами, зокрема з ліпідами, вуглеводами, протеїнами 
і ДНК, змінюючи їх структуру та фрункції. Результатом цього є ушкодження клітин, що призводить до патологічних процесів, а саме розвитку атеросклерозу.

Відомо, що важкі метали, такі, як свинець, кадмій, мідь, ртуть та їх сполуки, належать до токсикантів політропної дії, що мають здатність уражати різні органи і системи (кровотворну, нервову, травну, сечовидільну, ендокринну, серцево-судинну). Вони блокують SH-групи протеїнів-ензимів, чим порушують їх каталітичну функцію, порушують фрункції клітинних мембран шляхом стимулювання в них генерації АФО і вільнорадикальних процесів [6].

3 літературних джерел відомо, що вільні амінокислоти і низькомолекулярні пептиди проявляють антиоксидантну властивість [7].

Мета дослідження - вивчити вплив Плюмбуму ацетату, Купруму сульфрату і гліфосату в формі раундапута коригувальнудіюцистеїл-гістидил-тирозил-гістидил-ізолейцину на окиснювальні процеси в щурів різного віку.

МЕТОДИ ДОСЛІДЖЕННЯ. 3 метою вивчення впливу важких металів у поєднанні з фроссророрганічними пестицидами на окиснювальні процеси використовували лабораторних нелінійних білих щурів-самців 3 вікових періодів: статевонезрілих (молодих масою 70-90 г і віком 1-3 місяці), статевозрілих (дорослих масою 170-210 г і віком 5-8 місяців), старих (масою 250-300 г і віком 20-24 місяці). Вік тварин визначали за схемою В. І. Махінько та В. Н. Нікітіна [8].

Інтоксикацію в щурів моделювали шляхом щоденного перорального введення їм упродовж 30 діб водних розчинів Плюмбуму ацетату $\left(\left(\mathrm{CH}_{3} \mathrm{COO}\right)_{2} \mathrm{~Pb}\right)$ у дозі 11 мг/кг маси тіла $\left(1 / 20 \mathrm{LD}_{50}\right)$, Купруму сульфрату (CuSO ${ }_{4}$ в дозі 13 мг/кг маси тіла $\left(1 / 20 L_{50}\right)$, гліфосату (у формі гербіциду раундапу) в дозі 250 мг/кг маси тіла (1/20 LD $\left.{ }_{50}\right)$. Токсиканти вводили в комбінації та окремо. Як контроль використовували інтактних тварин, яким вводили питну водопровідну дехлоровану воду. 3 метою корекції виявлених порушень на 21-й день експерименту через 6 год після введення токсикантів щодня протягом 10 днів вводили пептид цистеїл-гістидил-тирозил-гістидил-ізолейцин у дозі 9 мг/кг маси тіла (концентрації амінокислот у крові).

Піддослідних тварин усіх вікових періодів було поділено на такі групи: 1-ша - інтактні (контрольні); 2-га - комбіноване ураження водними розчинами Плюмбуму ацетату, Купруму сульфату і раундапу; 3-тя - з корекцією пептидом. На 31-шу добу після останнього введення ксенобіотиків щурів виводили з експерименту за умов використання тіопентал-натрієвого (внутрішньо- черевне введення $1 \%$ розчину з розрахунку 50 мг/кг маси тварини) наркозу.

Вміст ТБК-активних продуктів визначали за [9], дієнових кон'югатів (ДК) - за [10], окисномодифікованих протеїнів (ОМП) - за [11].

Під час проведення досліджень усі щури перебували у віварії Тернопільського національного медичного університету імені І. Я. Горбачевського МОЗ України на стандартному раціоні відповідно до санітарно-гігієнічних норм. Утримували щурів та виконували всі експерименти на них із дотриманням національних (Закон України № 3447-IV "Про захист тварин від жорстокого поводження", 2006) та міжнародних (Європейська конвенція про захист хребетних тварин, що використовуються для дослідних та інших наукових цілей, Страсбург, 1986) загальних правил і рекомендацій щодо гуманного поводження з лабораторними тваринами [12-14].

Статистичну обробку циорових даних здійснювали за допомогою програмного забезпечення Excel ("Microsoft", США) і STATISTICA 6.0 ("Statsoft", США) з використанням непараметричних методів оцінки одержаних даних. Для всіх показників розраховували значення середньої арисрметичної вибірки (М), її дисперсії і помилки середньої (m). Достовірність різниці значень між незалежними кількісними величинами встановлювали за допомогою критерію Манна - Уїтні. Зміни вважали статистично достовірними при $\mathrm{p}<0,05$ [15].

РЕЗУЛЬТАТИ Й ОБГОВОРЕННЯ. ДЛЯ ОЦінКИ стану вільнорадикального окиснення ліпідів ми визначали вміст дієнових кон'югатів і ТБК-активних продуктів, які найчастіше досліджують $[5,16]$.

Дієнові кон'югати є первинними продуктами пероксидного окиснення ліпідів, які утворюються при надмірному вмісті АФО, і призводять до деградації клітинних мембран [3]. Результати дослідження рівня ДК за умов токсичного ураження печінки показали, що він підвищувався при дії ксенобіотиків як у плазмі, так і в печінці щурів усіх вікових груп (табл. 1). Проте найбільшого токсичного впливу зазнавали молоді тварини. Так, при комбінованій дії досліджуваних токсикантів вміст ДК у печінці 3-місячних щурів становив $181 \%$, а в 6- і 18-місячних - 158 та 151 \% від норми. У крові динаміка вмісту дієнових кон'югатів мала аналогічну тенденцію.

У таблиці 1 наведено результати дослідження вмісту ТБК-активних продуктів у плазмі крові й тканині печінки інтактних та уражених ксенобіотиками тварин різного віку.

Як свідчать дані таблиці, вміст ТБК-активних продуктів у здорових тварин з віком збільшувався. Так, їх рівень у печінці статевонезрілих щурів 
Таблиця 1 - Вміст ТБК-активних продуктів і дієнових кон'югатів у сироватці крові та гомогенаті печінки щурів за умов комбінованої дії Купруму сульфрату, Плюмбуму ацетату, гліфосату (в фоормі раундапу) та при введенні пептиду ( $\mathrm{M} \pm \mathrm{m}, \mathrm{n}=10)$

\begin{tabular}{|c|c|c|c|c|}
\hline \multirow[b]{2}{*}{ Група тварин } & \multicolumn{2}{|c|}{ ТБК-активні продукти } & \multicolumn{2}{|c|}{ Дієнові кон'югати } \\
\hline & $\begin{array}{c}\text { сироватка крові, } \\
\text { ммоль/л }\end{array}$ & $\begin{array}{l}\text { гомогенат печінки, } \\
\text { нмоль×мг-1 протеїну }\end{array}$ & 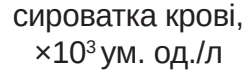 & 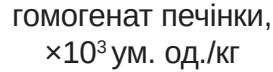 \\
\hline \multicolumn{5}{|c|}{ Статевонезрілі } \\
\hline Інтактні & $6,11 \pm 0,23$ & $37,35 \pm 1,03$ & $1,03 \pm 0,02$ & $5,40 \pm 0,20$ \\
\hline Уражені & $7,18 \pm 0,33^{\star}$ & $56,84 \pm 2,36^{\star}$ & $1,74 \pm 0,04^{*}$ & $9,77 \pm 0,28$ \\
\hline Кориговані & $6,29 \pm 0,12$ & $37,56 \pm 1,19$ & $1,09 \pm 0,02^{\star *}$ & $5,65 \pm 0,20$ ** \\
\hline \multicolumn{5}{|c|}{ Статевозрілі } \\
\hline Інтактні & $6,43 \pm 0,27$ & $39,05 \pm 1,24$ & $1,11 \pm 0,03$ & $6,24 \pm 0,20$ \\
\hline Уражені & $8,51 \pm 0,18^{\star}$ & $56,84 \pm 2,36^{\star}$ & $2,11 \pm 0,03^{*}$ & $9,88 \pm 0,58^{*}$ \\
\hline Кориговані & $6,53 \pm 0,20^{\star \star}$ & $40,02 \pm 1,17^{* \star}$ & $1,16 \pm 0,04^{\star \star}$ & $6,47 \pm 0,27^{* \star}$ \\
\hline \multicolumn{5}{|c|}{ Старі } \\
\hline Інтактні & $6,96 \pm 0,26$ & $42,68 \pm 0,56$ & $1,31 \pm 0,04$ & $7,10 \pm 0,20$ \\
\hline Уражені & $10,75 \pm 0,26^{\star}$ & $70,90 \pm 1,15^{*}$ & $2,91 \pm 0,13^{*}$ & $10,70 \pm 0,14^{*}$ \\
\hline Кориговані & $7,25 \pm 0,16^{\star \star}$ & $48,07 \pm 0,32^{\star \star}$ & $1,45 \pm 0,32^{\star \star}$ & $7,47 \pm 0,39^{\star \star}$ \\
\hline
\end{tabular}

Примітка. Тут і в таблиці 2: * - результати достовірні відносно інтактних тварин (р<0,05); ** - результати достовірні відносно показників у щурів при комбінованому ураженні $(p<0,05)$.

становив $(37,35 \pm 1,03)$ мкмоль/кг і був нижчим на 4,6 та 14,3 \% порівняно з аналогічним показником у дорослих і старих тварин, а в плазмі крові складав $(6,11 \pm 0,23)$ мкмоль/ л - на 5,2 і 13,9 \% відповідно (p<0,05). При комбінованій дії ксенобіотиків вміст ТБК-активних продуктів у сироватці крові молодих щурів зріс в 1,3 раза, дорослих в 1,2 раза, старих - в 1,5 раза від рівня контролю. Збільшувався він також і в гомегенаті печінки.

Як показали результати досліджень останніх років, активні форми Оксигену, що утворюються під час метаболізму ксенобіотиків, зумовлюють пероксидацію ліпідів, нуклеїнових кислот і протеїнів [3]. Про ступінь окиснювальної модифрікації протеїнів судили за вмістом альдегідо- і кетонопохідних протеїнів нейтрального й основного характеру.

Як видно з даних, наведених у таблиці 2, 3 віком у здорових тварин вміст ОМП зростав. Так, вміст альдегідо- і кетонопохідних нейтрального характеру $\left(\mathrm{OMБ}_{370}\right)$ у старих щурів перевищував аналогічний показник молодих та дорослих на 27 і 13 \%, тоді як рівень альдегідо- і кетонопо- хідних основного характеру $\left(\mathrm{OMБ}_{430}\right)$ - на 15 та 3 \% відповідно. Ці результати вказують на підвищення у здорових тварин чутливості протеїнів до окиснювальної модиорікації в процесі старіння.

При введенні токсикантів виразних змін зазнавали також показники окиснювальної модиорікації протеїнів в уражених тварин різного віку. Зростання вмісту альдегідо- та кетонопохідних нейтрального характеру відмічено в усіх вікових групах, однак максимальні зміни ОМП ми спостерігали у молодих і старих щурів. Так, рівень альдегідо- та кетонопохідних нейтрального характеру $\left(O M \Pi_{370}\right)$ перевищував аналогічний показник інтактних молодих і старих тварин у плазмі крові в 1,7 та 1,9 раза, а основного характеру $\left(О М \Pi_{430}\right)$ - в 1,8 й 1,9 раза $(\mathrm{p}<0,05)$.

При порівняльному аналізі показників вільнорадикального окиснення ліпідів з показниками окиснювальної модиорікації протеїнів (табл. 1 і 2) спостерігали подібні зміни ліпідів та протеїнів. Це свідчить про взаємозалежність 2 процесів вільнорадикального окиснення ліпідів та окисню-

Таблиця 2 - Динаміка вмісту альдегідо- та кетонопохідних нейтрального $\left(\mathrm{OMП}_{370}\right)$ й основного $\left(O \Pi_{430}\right)$ характеру (моль/кг) у сироватці крові щурів різного віку за умов введення Купруму сульфату, Плюмбуму ацетату, гліфосату (в формі раундапу) та пептиду як коригувального чинника ( $\mathrm{M} \pm \mathrm{m}, \mathrm{n}=10)$

\begin{tabular}{||l|c|c|}
\hline \multirow{2}{*}{ Група тварин } & \multicolumn{2}{|c|}{ Показник } \\
\cline { 2 - 3 } & \multicolumn{2}{|c|}{ ОМП $_{370}$} \\
\hline \multicolumn{3}{|c|}{ Статевонезрілі } \\
\hline Інтактні & $0,65 \pm 0,03$ & $0,52 \pm 0,02$ \\
\hline Уражені & $1,12 \pm 0,03^{*}$ & $0,92 \pm 0,02^{*}$ \\
\hline Кориговані & $0,69 \pm 0,02$ & $0,58 \pm 0,02^{\star \star}$ \\
\hline \multicolumn{3}{|c|}{ Статевозрілі } \\
\hline Інтактні & $0,74 \pm 0,02$ & $0,58 \pm 0,02$ \\
\hline Уражені & $1,16 \pm 0,02^{*}$ & $0,90 \pm 0,03^{*}$ \\
\hline Кориговані & $0,79 \pm 0,02^{\star *}$ & $0,60 \pm 0,02^{\star *}$ \\
\hline
\end{tabular}


вальної модифрікації протеїнів у перебізі патологічних процесів і вимагає адекватних методів корекції. Тому ми з метою корекції використовували низькомолекулерний пептид.

При такій корекції концентрація ДК, ТБК-активних продуктів і окисномодиорікованих протеїнів наближалася до норми - рівня інтактних тварин.

Отже, підсумовуючи результати проведених досліджень, можна стверджувати, що використані токсиканти впливають на процеси окиснення у тварин усіх вікових груп. Застосування 3 метою корекції пептиду призвело до зниження вмісту продуктів окиснення, що вказує на його антиоксидантні й мембраностабілізувальні властивості.

ВИСНОВКИ. 1. Ураження тварин Плюмбуму ацетатом, Купруму сульфатом, раундапом супроводжується активацією вільнорадикального окиснення як ліпідів, так і протеїнів у сироват- ці крові, яка залежить від віку. В старих тварин вміст продуктів окиснювальної модифрікації протеїнів переважає над їх рівнем у дорослих і молодих щурів.

2. Інтоксикація щурів важкими металами і раундапом призводить до активації процесів вільнорадикального окиснення ліпідів в усіх трьох вікових групах тварин. Найбільших змін вони зазнають у старих щурів.

3. Застосування з метою корекції пепдиду наближає до норми показники процесів вільнорадикального окиснення у тварин усіх вікових груп, що, очевидно, пов'язано з його антиоксидантними і мембраностабілізувальними властивостями.

Перспективи подальших досліджень. Заплановано вивчити коригувальну дію низькомолекулярних пептидів на показники ліпідного обміну в щурів, уражених Купруму сульфатом, Плюмбуму ацетатом і раундапом.

\section{СПИСОК ЛІТЕРАТУРИ}

1. Finkel T. Oxidantsignals and oxidative stress / T. Finkel // Current Opinionin Cell Biology. - 2003. 15 (2). - P. 247-254.

2. Нетюхайло Л. Г. Активні форми кисню (Огляд літератури) / Л. Г. Нетюхайло, С. В. Харченко // Молодий вчений. - 2014. - № 9 (12). - С. 131-135.

3. Хисматуллина 3. Н. Сущность, направление и роль окислительно-восстановительных реакций в биологии и медицине / 3. Н. Хисматуллина // Вестн. Казан. технол. ун-та. - 2011. - № 19. - С. 35-41.

4. Левин Г. Я. Роль перекисного окисления липидов в агрегации клеток крови при ожоговой болезни / Г. Я. Левин, М. Н. Егорихина // Клин. лаб. диагностика. - 2008. - № 8. - С. 43-44.

5. Gutteridge J. M. Antioxidants: molecules, medicines and myths / J. M. Gutteridge, B. Halliwell // Biochem. Biophys. Res. Commun. - 2010. - 393. - P. 564.

6. К клинике и лечению неврологических и абдоминальных нарушений при хронической свинцовой интоксикации / Г. М. Балан, И.В.Юрченко, Л. В. Игнатенко [и др.] // Совр. пробл. токсикол. - 2003. - № 4. C. $50-56$.

7. Болдырев А. А. Биомембранология : учеб. пособ. / А. А. Болдырев, Е. И. Кяйвяряйнен, В. А. Илюха. - Красноярск : Сибирский федеральный ун-т, 2008. - 186 c.

8. Махинько В. И. Константы роста и фрункциональные периоды развития в постнатальной жизни белых крыс / В. И. Махинько, В. Н. Никитин // Моле- кулярные и оризиологические механизмы возрастного развития. - К. : Наукова думка, 1975. - С. 308-326.

9. Крась С. І. Тканинна специсріка фрункціонування антиоксидантної системи та пероксидного окислення ліпідів в амурського сазана різних вікових груп / С. І. Крась, С. І. Тарасюк // Укр. біохім. журн. - 2011. 83, № 4. - C. 77-83.

10. Камышников В. С. Справочник по клинико-биохимической лабораторной диагностике / В. С. Камышников. - Минск : Беларусь, 2002. - 1. - С. 546-447.

11. Мещишен І. Ф. Механізм окиснювальної модисрікації білків / І. Ф. Мещишен, В. П. Польовий // Буковин. мед. вісн. - 1999. - 3, № 1. - С. 196-205.

12. Про захист тварин від жорстокого поводження : Закон України від 21.02.2006 р. № 3447-IV.

13. Науково-практичні рекомендації з утримання лабораторних тварин та роботи з ними / Ю. М. Кожем'якін, О. С. Хромов, М. А. Філоненко, Г. А. Сайсретдінова. - К. : Авіцена, 2002. - 156 с.

14. European convention for the protection of vertebrate animals used for experimental and other scientific purposes. - Council of Europe. Strasbourg, 1986. No. 123. -52 p.

15. Bernard Rosner. Fundamentals of Biostatistics. Boston, USA. - 2010. - 859 p.

16. Dietert R. R. Lead and Immune Function / R. R. Dietert, M. S. Piepenbrink // Crit. Rev. Toxicol. 2006 - No. 36. - P. 359-385. 


\section{REFERENCES}

1. Finkel, T. (2003). Oxidant signals and oxidative stress. Current Opinionin Cell Biology, 15, 254.

2. Netiykhailo, L.H., \& Kharchenko, S.V. (2014). Aktyvni formy kysniu (ohliad literatury) [Active forms of oxygen (Literature overview)]. Molodyi vchenyi - Young Scientist, 9 (12), 131-135 [in Ukrainian].

3. Levin, G.Ya., \& Egorikhina, M.N. (2008). Rol perikesnogo okisleniya lipidov $v$ agregatsii kletok krovi pri ozhogovoy bolezni [Role of lipid peroxidation in aggregation of blood cells in case of burn disease]. Klin. lab. diagnostika - Clinical Laboratory Diagnostics, 8, 43-44 [in Russian].

4. Gutteridge, J.M., \& Halliwell, B. (2010). Antioxidants: molecules, medicines and myths. Biochem. Biophys. Res. Commun., 393, 564.

5. Zavorotnaya, R.M. (2002). Singletniy kislorod pri lechenii ryada patologicheskikh protsesov: fizikokhimicheskie aspekty [Singlet oxygen in the treatment of a number of pathological processes: physical and chemical aspects]. Ukr. revmatol. zhurnal - Ukrainian Rheumatological Journal, 1, 35-37 [in Russian].

6. Balan G.M., Yurchenko, I.V., \& Ignatenko, L.V. (2003). K klinike i lecheniyu nevrologicheskikh i abdominalnykh narusheniy pri khronicheskoy svintsovoy intoksikatsii [Clinic and treatment of neurological and abdominal disorders with chronic lead intoxication]. Sovrem. probl. toksikologii - Modern Problems of Toxicology, 50-56 [in Russian].

7. Boldyrev, A.A., Kayvyaryaynen, V.A., \& llyukha, V.A. (2008). Biomembranologiya: ucheb. posobie [Biomembranology: Textbook]. Krasnoyarsk: Siberian Federal University [in Russian].

8. Makhinko, V. I., \& Nikitin, V. N. (1975). Konstanty rosta i funktsionalnyie periody razvitiya $v$ postnatalnoy zhizni belykh krys [Growth constants and functional development periods in the postnatal life of white rats].
Molekulyarnye i fiziologicheskie mekhanizmy vozrastnogo razvitiya - Molecular and physiological mechanisms of age development. Kyiv [in Russian].

9. Kras, S.I., \& Tarasiuk, S.I. (2011). Tkanynna spetsyfika funktsionuvannia antyoksydantnoho okyslennia lipidiv v amurskoho sazana riznykh vikovykh hrup [Tissue specificity of the functioning of the antioxidant system and peroxide oxidation of lipids in the Amur sazan of different age groups]. Ukr. biokhim. zhurn. - Ukrainian Biochemical Journal, 83 (4), 77-83 [in Ukrainian].

10. Kamyshnikov, V.S. (2002). Spravochnik po klinikobiokhimicheskoy laboratornoy diagnostike [Reference book on clinical and biochemical laboratory diagnostics]. Minsk: Belarus [in Russian].

11. Meshchyshen, I.F. (1998) Metod vyznachennia okysniuvalnoi modyfikatsii bilkiv plazmy (syrovatky) krovi [Method of determining the oxidative modification of plasma proteins (serum) blood]. Bukovynskyi medychnyi visnyk - Bukovynian Medical Journal, 2 (1), 156-158 [in Ukrainian].

12. Zakon Ukrainy "Pro zakhyst tvaryn vid zhorstokoho povodzhennia" vid 21.02.2006 r., No 3447 [The Law of Ukraine "On the Protection of animals from ill-treatment" of 02.21. 006, No. 3447]. [in Ukrainian].

13. Kozhemiakin, Yu.M., Khromova, O.S., \& Filonenko, M.A. (2002). Naukovo-praktychni rekomendatsii z utrymannia laboratornykh tvaryn ta robota $z$ nymy [Scientific and practical recommendations for the maintenance of laboratory animals and work with them]. Kyiv: Avitsena [in Ukrainian].

14. (1986). European convention for the protection of vertebrate animals used for experimental and other scientific purposes Council of Europe. Strasbourg.

15. Bernard Rosner. (2010). Fundamentals of Biostatistics. Boston, USA.

16. Dietert, R.R. \& Piepenbrink, M.S. (2006). Lead and Immune Function. Crit. Rev. Toxicol., 36, 359-385.

Е. Б. Дмухальская, Т. Я. Ярошенко ТЕРНОПОЛЬСКИЙ НАЦИОНАЛЬНЫЙ МЕДИЦИНСКИЙ УНИВЕРСИТЕТ ИМЕНИ И. Я. ГОРБАЧЕВСКОГО МОЗ УКРАИНЫ

\section{ОКИСЛИТЕЛЬНАЯ МОДИФИКАЦИЯ ПРОТЕИНОВ У КРЫС РАЗНОГО ВОЗРАСТА В УСЛОВИЯХ ХРОНИЧЕСКОГО ПОРАЖЕНИЯ ТЯЖЕЛЫМИ МЕТАЛЛАМИ И ГЛИФОСАТОМ}

\section{Резюме}

Вступление. Известно, что влияние различных загрязнителей окружающей среды, таких, как тяжелые металлы и фросфорорганические соединения, вызывает различные изменения в организме человека, которые сопровождаются нарушением баланса между процессами окисления и восстановления, образованием активных фрорм кислорода, что объясняет развитие оксидантного стресса. Ионы тяжелых металлов могут индуцировать образование активных фрорм кислорода. Сегодня коррекция нарушений свободнорадикальных и антиокситантних процессов при комбинированном действии тяжелых металлов и фроссророрганических пестицидов остается не до конца изученной.

Цель исследования - изучить влияние ацетата свинца, сульфрата меди, глифосата в фрорме раундапа и корректирующее действие цистеил-гистидил-тирозил-гистидил-изолейцина на окислительные процессы у крыс разного возраста.

Методы исследования. Опыты проводили на лабораторных нелинейных белых крысах-самцах з возрастных групп: неполовозрелых, половозрелых и старых, которым внутрижелудочно в течение 
30 дней вводили водные растворы ацетата свинца, сульфата меди и глифосата (в фрорме гербицида раундапа). С целью коррекции на 21-й день через 6 ч после введения токсикантов в течение 10 дней вводили пептид цистеил-гистидил-тирозил-гистидил-изолейцин. Оксидантный стресс оценивали по уровню окислительномодифицированных протеинов, содержанию ТБК-активных продуктов и диеновых конъюгатов в сыворотке крови и гомогенатах печени.

Результаты и обсуждение. Установлено, что при введении крысам водных растворов ацетата свинца, сульфрата меди и глифросата (в фрорме гербицида раундапа) в комбинации активировались окислительные процессы в сыворотке крови и гомогенате печени пораженных крыс. Одновременное введение исследуемых ксенобиотиков животным всех возрастных групп вызывало увеличение содержания ТБК-активных продуктов и диеновых конъюгатов в сыворотке крови и гомогенате печени. Интоксикация сульфратом меди, ацетатом свинца и фросфророрганическим пестицидом сопровождалась нарушением баланса между про- и антиоксидантами, развитием оксидантного стресса, что может вызвать фрункциональные и структурные повреждения клеточных мембран и накопление токсичных метаболитов. При использовании пептида как фрактора коррекции уменьшалось содержание активных форм кислорода и продуктов перекисного окисления липидов.

Вывод. Введение пептида как корректирующего фрактора крысам с токсическим пораженем печени снижает генерацию активных фрорм кислорода и содержание продуктов свободнорадикального окисления липидов.

КЛЮЧЕВЫЕ СЛОВА: свободные радикалы; свободнорадикальное окисление; ацетат свинца; сульфат меди; глифосат.

Ye. B. Dmukhalska, T. Ya. Yaroshenko

I. HORBACHEVSKY TERNOPIL NATIONAL MEDICAL UNIVERSITY

\section{OXIDATIVE MODIFICATION OF PROTEINS IN RATS OF DIFFERENT AGE UNDER CONDITIONS OF CHRONIC AFFECT WITH HEAVY METALS AND GLYPHOSATE}

\section{Summary}

Introduction. It is known that the effects of various environmental pollutants, such as heavy metals and organophosphorus compounds, cause various changes in the human body, accompanied by imbalances between oxidation and reduction, the formation of reactive oxygen species, which explains the development of oxidative stress. Heavy metal ions can induce the formation of reactive oxygen species. To date, the correction of violations of free radical and antioxidant processes by the combined action of heavy metals and organophosphorus pesticides remains incompletely studied.

The aim of the study - to investigate the effect of lead acetate, copper sulfate and glyphosate in the form of a roundup and the corrective effect of cysteyl-histidyl-tyrosyl-histidyl-isoleucine on oxidative processes in rats of different ages.

Research Methods. The experiments were carried out on laboratory nonlinear white male rats of 3 age groups: immature, sexually mature and old, which were intragastrically injected for 30 days with aqueous solutions of lead acetate, copper sulfate and glyphosate (in the form of Roundup herbicide). For the purpose of correction, on the 21st day, 6 hours after the administration of toxicants, the peptide cysteyl-histidyl-tyrosyl-histidyl-isoleucine was administered for 10 days. Oxidative stress was assessed by the level of oxidatively modified proteins, the content of TBA-active products and diene conjugates in blood serum and liver homogenates.

Results and Discussion. It was found that the administration of aqueous solutions of lead acetate, copper sulfate and glyphosate (in the form of Roundup herbicide) in combination with rats is accompanied by activation of oxidation processes in the serum and liver homogenates of the affected animals. Simultaneous administration of the studied xenobiotics to animals of all ages caused an increase in the content of TBA-active products (TBA-AP) and diene conjugates (DC) in blood serum and liver homogenates. Intoxication of copper with sulfate, lead acetate and organophosphorus pesticide was accompanied by imbalance between pro- and antioxidants, the development of oxidative stress, which can cause functional and structural damage to cell membranes and the accumulation of toxic metabolites. When the peptide is used as a correction factor, the content of reactive oxygen species and lipid peroxidation products decreases.

Conclusion. The administration of the peptide as a corrective factor to rats with toxic liver damage reduces the generation of reactive oxygen species and the content of free radical lipid oxidation products.

KEY WORDS: free radicals; free radical oxidation; glyphosate; lead acetate; copper sulfate.

Отримано 19.03.21

Адреса для листування: Є. Б. Дмухальська, Тернопільський національний медичний університет імені І. Я. Горбачевського мОз України, майдан Волі, 1, Тернопіль, 46001, Україна, e-mail: dmukhalska@tdmu.edu.ua. 